\title{
PERBANDINGAN PRESTASI BELAJAR ANTARA SISWA DENGAN ORANGTUA TUNGGAL DAN SISWA DENGAN ORANGTUA UTUH
}

\author{
Nurjaman Hidayatulloh \\ Fakultas Psikologi UIN Sunan Gunung Djati Bandung, Jl. A.H Nasution No. 105 Bandung \\ email: nurris08@gmail.com
}

\begin{abstract}
Abstrak
Penelitian yang dilakukan pada siswa kelas XII Madrasah Aliyah Negeri (MAN) Cililin ini berawal dari ketertarikan peneliti untuk melihat bagaimana perbandingan prestasi belajar antara siawa dengan orangtua tunggal dan siawa dengan orangtua utuh, karena menurut guru BP (Bimbingan dan Penyuluhan) Madrasah Aliyah tersebut ada diantaranya siswa yang bermasalah dengan prestasi akademik karena ketunggalan orang tua mereka, baik karena bercerai ataupun karena meninggal dunia. Dalam penelitian ini dilakukan studi komparasi yang bertujuan untuk mengetahui perbandingan prestasi siswa dengan orang-tua tunggal dan utuh. Metoda penelitian yang digunakan adalah metoda penelitian kuantitatif. Sedangkan analisis yang digunakan adalah analisis komparasi. Dan pengambilan sampel dilakukan dengan menggunakan teknik non random purposive sampling dan simple random sampling. Alat ukur yang digunakan adalah nilai raport. Hasil analisis data memperlihatkan bahwa $p_{\text {value }}$ lebih kecil daripada $\alpha$. Hal ini memiliki arti bahwa $\mathrm{H}_{\mathrm{o}}$ ditolak dan $\mathrm{H}_{1}$ diterima, sehingga dapat dikatakan bahwa terdapat perbedaan prestasi belajar antara siswa dengan orangtua tunggal dan siswa dengan orangtua utuh pada siswa kelas XII Madrasah Aliyah Negeri (MAN) Cililin Kabupaten Bandung Barat.
\end{abstract}

Kata kunci: prestasi belajar, orangtua tunggal, dan orangtua utuh

\section{Abstract}

This research is done on the students at twelfth grade at MAN Cililin Bandung. The researcher feels interesting to investigate the comparison of study achievement between the students who have single parent and the students who have complete parent. According to the teacher of guidance and counseling, there is a problem in academic achievement for the students who have a single parent. This research uses the study comparison to know the achievement comparison of the students who have single or complete parents. The research uses the quantitative method and uses comparison analysis. The sample uses non random purposive sampling and simple random sampling. The tool of measurement uses the report score. The result of data analysis shows that $p_{\text {value }}$ is lower than $\alpha$. It means that $H_{o}$ is rejected and $H_{1}$ is accepted. There is the differences between the students who have single parent and the students who have complete parent.

Keywords: study achievement, single parents, and complete parents 


\section{PENDAHULUAN}

Sekolah merupakan sarana pendidikan formal, tempat semua orang mencari dan menuntut ilmu. Di sekolah semua siswa mendapatkan berbagai informasi dan pengalaman baru sehingga diharapkan terjadi perubahan dalam intelektual dan perilaku mereka. Mengingat pentingnya fungsi sekolah, maka setiap orang diharapkan dapat memperoleh pendidikan yang layak sebagai salah satu jaminan untuk masa depannya.

Dalam UU Sisdiknas No. 20 Bab I Pasal I (2003 : 3) dinyatakan bahwa pendidikan adalah usaha sadar dan terencana untuk mewujudkan susana belajar dan proses pembelajaran agar peserta didik secara aktif dapat mengembangkan potensi dirinya untuk memiliki kekuatan spiritual keagamaan, pengendalian diri, kepribadian, kecerdasan, akhlak mulia, serta keterampilan yang diperlukan dirinya, masyarakat, bangsa dan negara.

Sekolah merupakan lembaga pendidikan formal yang secara sistematik melaksanakan program bimbingan, pengajaran, dan latihan dalam rangka membantu siswa agar mampu mengembangkan potensinya, baik yang menyangkut aspek moral-spiritual, intelektual, emosional maupun sosial (Yusuf, 2000 : 95).

Masalah pendidikan merupakan faktor penting dalam pembangunan manusia seutuhnya, karena kemampuan, kecerdasan, dan kepribadian suatu bangsa yang akan datang ditentukan oleh pendidikan yang ada sekarang, bahkan kemajuan suatu masyarakat atau bangsa banyak ditentukan oleh pendidikannya. Karena itu pendidikan memegang peranan sentral dalam pembangunan manusia seutuhnya dan masyarakat seluruhnya, sebab selain menjadi subjek pembangunan, manusia juga berperan sebagai objek pembangunan, serta manusia itu sendiri akan menikmati hasil pembangunannya (Nasir, 1999 : 17).

Seiring perkembangan zaman, persoalan hidup manusia semakin kompleks. Manusia dihadapkan pada berbagai persoalan hidup yang harus dihadapi setiap saat. Akan tetapi tidak semua individu mampu keluar dari persoalan hidup, karena memang pada dasarnya manusia terlahir dalam kondisi yang tidak berdaya, tanpa mempunyai pengetahuan sedikitpun tentang sesuatu hal untuk menghadapi hidup.

Manusia sebagai makhluk sosial dituntut untuk mampu mengatasi segala permasalahan yang timbul sebagai hasil dari interaksi dengan lingkungan, baik lingkungan sosial dengan ruang lingkup kecil (misalnya keluarga) atau ruang lingkup besar (misalnya masyarakat). Begitupun bagi seorang anak, dia harus mampu menghadapi permasalahan yang terjadi di sekitarnya, baik dengan masyarakat, teman maupun keluarga.

Keluarga merupakan kelompok sosial pertama dalam kehidupan sosial. Di dalam keluarga, manusia pertama kali memperhatikan keinginan orang lain, belajar bekerja sama, dan belajar membantu orang lain (Suhendi dkk., 2001: 61). Pengalaman berinteraksi dalam keluarga akan menentukan tingkah laku dalam kehidupan sosial di luar keluarga.

Keluarga merupakan unit sosial terkecil yang bersifat universal dan satuan unit sosial terkecil yang memberikan pondasi bagi pengembangan anak, terutama dalam kepribadiannya. Inilah yang dikatakan bahwa keluarga merupakan inti dari masyarakat (Suhendi dkk., 2001: 61).

Keluarga merupakan sistem sosial yang terdiri dari berbagai subsistem yang berhubungan dan saling mempengaruhi satu sama lain. Subsistem dalam keluarga adalah fungsi-fungsi hubungan antaranggota keluarga yang ada dalam keluarga, seperti fungsi hubungan ayah dengan ibu, anak dengan ayah, anak dengan ibu, dan sebagainya (Effendi, 1993 : 35).

Seorang anak pada awalnya akan bergantung kepada orang tuanya dan orang-orang yang berada di sekitarnya hingga waktu tertentu. Seiring dengan berlalunya waktu dan perkembangan selanjutnya, seorang anak diharapkan mampu melepaskan diri dari ketergantungan menuju kemandirian. Hal ini merupakan suatu yang alamiah atau secara umum dialami oleh setiap individu sebagai makhluk sempurna yang diciptakan oleh Allah Subhanahu wa Ta'ala. Karena itu individu diharapkan mampu menghadapi semua persoalanpersoalan hidup yang ada di sekitarnya.

Kemampuan menyelesaikan masalah harus dimiliki oleh setiap individu, karena hal tersebut merupakan bekal yang sangat pokok untuk menghadapi permasalahan hidupnya. Berdasarkan kemampuan itu, individu diharapkan mampu berkembang untuk menjadi individu yang bermanfaat bagi diri dan lingkungan.

Orang dewasa memiliki permasalahan yang lebih kompleks lagi, selain harus mengurus diri sendiri, seorang dewasa juga dituntut untuk mampu mengurus dan membina hu- 
bungan baik dengan orang yang ada di sekitarnya, diantaranya orang tua, pasangan hidup dan anak-anaknya.

Hubungan yang tidak terbina dengan baik antar anggota keluarga, misalnya antara suami dengan isteri, suami dengan orang tua isteri, isteri dengan orang tua suami, atau bahkan anak dengan orang tuanya terkadang dapat menjadi sumber munculnya masalah dalam sebuah keluarga yang terkadang sulit untuk diselesaikan.

Keluarga tunggal (single parent) merupakan sutau permasalahan yang sering terjadi disekeliling kita. Suhendi dkk. (2001: 140) menyebutkan bahwa keluarga yang terdiri dari orangtua tunggal baik ayah atau ibu sebagai akibat perceraian dan kematian disebut dengan single parent. Keluarga single parent dapat diakibatkan oleh perceraian, kematian, orang tua angkat, dan orang tua yang berpisah tempat tinggal (belum bercerai).

Dalam menjalani kehidupan, setiap individu pasti akan dihadapkan dengan permasalahan sebagai latihan menuju kedewasaan, akan tetapi terkadang tidak semua individu mampu untuk mengatasi dan keluar dari semua permasalahan yang dihadapinya. Perceraian, kematian, atau jauh dari keluarga merupakan hal yang tidak diinginkan oleh siapapun, baik oleh ayah, ibu ataupun anak. Akan tetapi, kehidupan terkadang tidak sesuai dengan apa yang diharapkan.

Dalam kehidupan rumah tangga misalnya, permasalahan bisa timbul karena tuntutan ekonomi, perbedaan pendapat suami dengan isteri, pekerjaan, anak, ataupun permasalahanpermasalahan lainnya. Perceraian seringkali dijadikan jalan keluar oleh pasangan suami istri, jika sudah merasa tidak mampu untuk menyelesaikan permasalahan tersebut serta tidak ingin membiarkan anak hidup dalam konflik orang tuanya.

Pandangan perceraian sebagai salah satu jalan keluar sepintas memang masuk akal, karena biasanya orang tua lebih siap dalam menghadapi perceraian ini dibanding dengan anak-anaknya. Perceraian orang tua sering kali berakhir menyakitkan bagi seorang anak, karena anak harus beradaptasi dengan perubahanperubahan yang terjadi di sekelilingnya. Bagi anak, adaptasi memerlukan waktu, karena pada awalnya anak sulit menerima kenyataan bahwa orang tuanya tidak bersama lagi. Selain itu, proses adaptasi pada setiap anak tidak sama.
Pasca perceraian orang tua, anak yang mampu beradaptasi tentunya tidak akan mengalami kesulitan yang berarti untuk meneruskan kehidupannya ke periode perkembangan selanjutnya. Akan tetapi, bagi anak yang gagal beradaptasi, maka persoalan yang sedang dihadapi akan terus terbawa hingga dewasa disertai dengan berbagai perasaan tidak nyaman, merasa ditolak, merasa diri tidak berarti, dan tidak dicintai. Tasmin (2002), dalam artikelnya mengatakan bahwa perasaan ditolak, tidak berharga, dan tidak dicintai ini dapat menyebabkan anak menjadi takut gagal dan takut menjalin hubungan yang dekat dengan orang lain atau lawan jenis saat ia beranjak dewasa.

Masa ketika perceraian terjadi merupakan masa yang kritis bagi anak, hal ini salah satunya disebabkan oleh berkurangnya kuantitas serta kualitas komunikasi dengan orang tua yang tidak lagi tinggal bersama. Selain itu, kemungkinan anak juga dihadapkan dengan berbagai pertanyaan atau bahkan ejekan yang muncul dari beberapa teman sebayanya. Berdasakan hal tersebut biasanya anak merasa tidak aman, merasa tidak diinginkan, sedih, kesepian, marah, kehilangan, merasa bersalah dan menyalahkan diri sendiri (Tasmin, 2002).

Permasalahan lain yang dihadapi anak adalah meninggalnya salah satu orang tua. Permasalahan yang sering muncul dan menjadi sumber masalah bagi anak yang salah satu orang tuanya meninggal, adalah terkadang anak suka mengalami kesedihan berlarut-larut misalnya saja dengan menangis selama berharihari bahkan berminggu-minggu sehingga berbagai perasaan dan pikiran yang berindikasi kurang wajar timbul menghantui kehidupannya.

Hal tersebut mungkin akan menjadi wajar jika anak mampu keluar dari permasalahan dan bangkit serta berpikir positif kedepan dengan menyadari bahwa kematian akan menghampiri semua makhluk hidup di dunia. Akan tetapi akan memunculkan masalah lain apabila anak secara terus menerus memikirkan peristiwa kematian orang tuanya tanpa disertai kesadaran tentang kenyataan hidup yang terjadi sehingga kesedihan pun menghinggapinya.

Tingkat kesedihan yang dialami oleh seorang individu tentunya akan berbeda dengan kesedihan yang dialami oleh individu lain. Misalnya, pengalaman ditinggal mati oleh salah satu anggota keluarga, atau adanya perpisahan karena perceraian, umumnya sama-sama bisa menimbulkan kesedihan. Namun seberapa be- 
sar intensitas dan dampak kesedihan tersebut bisa berbeda-beda bagi setiap individu. Demikian pula implikasi dari kondisi-kondisi tersebut, bisa bersifat negatif maupun sebaliknya bagi beberapa individu.

Selain dari masalah perceraian dan kematian orang tua, tentunya pola asuh dalam keluarga ikut mempengaruhi kondisi pasikologis anak. Pola asuh (parenting styles) adalah suatu metode yang dijalankan oleh orang tua dalam membesarkan anaknya, sehingga nantinya seorang anak diharapkan mampu bertingkah laku dengan baik di masyarakat (Papalia, 2002). Sedangkan menurut Slavin (dalam Hidayat, 2003) pola asuh orang tua adalah pola perilaku yang digunakan orang tua untuk berhubungan dengan anak - anak.

Menurut Baumrind (1971) (dalam Papalia, 2002: 281), terdapat tiga jenis pola asuh, yaitu: authoritarian, permissive dan authoritative. Authoritarian merujuk pada pola asuh dari orang tua yang lebih mengutamakan kontrol daripada affek kepada anaknya, mereka mencoba membuat anaknya merasa nyaman dengan berbagai aturan yang telah mereka buat dan tak segan memberikan hukuman jika anaknya melanggar aturan tersebut. Orang tua tipe ini juga cenderung memaksa, memerintah, tidak mengenal kompromi, dan dalam komunikasi biasanya bersifat satu arah. Orang tua tipe ini tidak memerlukan umpan balik dari anaknya untuk mengerti mengenai anaknya. Selain itu orang tua yang menggunakan pola asuh ini tidak menunjukkan kehangatan dan jarang melakukan interaksi dengan anaknya.

Hal yang sebaliknya terjadi pada jenis pola asuh permissive, pada bentuk pola asuh ini orang tua lebih mengutamakan affek daripada kontrol, orang tua sering berinteraksi dan menunjukkan kehangatan pada anaknya selain itu mereka membiarkan anaknya untuk memonitor tingkah lakunya sendiri namun tanpa adanya kontrol dan tuntutan. Orang tua juga cenderung tidak menegur atau memperingatkan anak apabila anak memasuki situasi yang berbahaya, dan sangat sedikit bimbingan yang diberikan oleh mereka. Namun orang tua tipe ini biasanya bersifat hangat, sehingga seringkali disukai oleh anak.

Pada jenis pola asuh ketiga, yaitu authoritative, orang tua memiliki berbagai aturan namun tetap menghargai keputusan, minat, opini dan kepribadian anak. Mereka menunjukkan kehangatan dan tetap melaksanakan aturan ya- ng telah dibuat dengan memberikan hukuman jika anak melanggar aturan, namun dalam konteks hubungan yang saling mendukung. Orang tua tipe ini juga bersikap realistis terhadap kemampuan anak, tidak berharap yang berlebihan yang melampaui kemampuan anak.

Berbagai akibat dari keluarga tunggal seperti karena perceraian, kematian, orang tua angkat, dan orang tua yang berpisah tempat tinggal, yang akan dijadikan penelitian oleh peneliti adalah anak dengan orangtua tunggal karena perceraian dan kematian orang tuanya.

Hal tersebut seperti tergambar pada fenomena yang terjadi pada beberapa siswa Madrasah Aliyah Negeri Cililin Kabupaten Bandung Barat.

Menurut guru BP di Madrasah Aliyah tersebut, ada beberapa siswa yang perlu diperhatikan dalam proses dan hasil belajarnya (dalam hal ini prestasi akademik siswa tiap semester) terutama dari siswa yang ditinggal pergi oleh salah satu orang tua mereka.

Beberapa siswa yang ditinggal cerai atau mati terkadang sering mengeluh dan menangis, terkadang ada yang malas untuk pergi sekolah bahkan ada yang ingin berhenti sekolah. Walaupun sebenarnya ada juga siswa yang merasa terpacu untuk lebih berprestasi ketika ditinggal pergi orang tua (baik ditinggal cerai atau meninggal). Hal tersebut diperoleh berdasarkan hasil wawancara peneliti yang dilaksanakan pada tanggal 02 April 2007 terhadap 16 siswa yang orang tuanya meninggal dan 6 siswa yang orang tuanya bercerai.

Berdasarkan studi pendahuluan, penulis melakukan observasi kepada 22 siswa dengan orangtua tunggal baik karena perceraian ataupun meninggal yang menunjukan bahwa 4 dari 6 siswa (67\%) merasa prestasinya menurun setelah orang tua mereka berpisah, dan 2 siswa (23\%) lainnya mengatakan terpacu untuk lebih giat lagi berprestasi. Selain itu 56\% (9 dari 16) anak yang orang tuanya meninggal mengatakan bahwa mereka merasa sedih dan tidak memiliki semangat lagi untuk belajar, karena tidak ada lagi yang membiayai kebutuhan sekolah, dan sisanya (44\%) merasa diri lebih terpacu dan ingin berprestasi di sekolah.

Dari adanya indikasi perbedaan dampak kepergian salah satu orang tua yang dirasakan oleh siswa itu terhadap pencapaian prestasi di sekolah, maka peneliti tertarik untuk melakukan penelitian lebih lanjut tentang Perbandingan Prestasi Belajar Antara Siswa dengan Or- 
angtua tunggal dan Siswa dengan Orangtua Utuh pada Siswa Kelas XII Madrasah Aliyah Negeri (MAN) Cililin Kabupaten Bandung Barat.

\section{Prestasi Belajar}

Keberhasilan suatu proses belajar dapt dilihat dari hasil belajar/prestasi belajar itu sendiri, karena prestasi belajar merupakan salah satu indikator yang sangat penting dalam keseluruhan proses pendidikan pada umumnya dan proses belajar pada khususnya. Prestasi belajar menunjukkan kepada tinggi rendahnya kualitas belajar siswa dalam pembelajarannya di sekolah. Selain itu, dapat dijadikan ukuran atau pedoman dalam memperbaiki proses belajar mengajar.

Kata prestasi belajar mengandung dua pengertian, yaitu prestasi dan belajar. Kata prestasi berasal dari bahasa Belanda yaitu prestatie, kemudian dalam bahasa Indonesia menjadi prestasi yang berarti hasil usaha (Arifin, 1988: 2). Sedangkan dalam kamus Besar Bahasa Indonsia (Depdikbud, 1988: 700) prestasi diartikan sebagai hasil usaha, sesuatu yang sudah dihasilkan atau dilakukan, sesuatu yang telah dicapai, baik itu dilakukan maupun dikerjakan.

Slameto (1993: 2) mendefinisikan, prestasi adalah suatu proses usaha yang dilakukan seseorang untuk memperoleh suatu perubahan tingkah laku yang baru secara keseluruhan sebagai hasil pengalamannya sendiri dalam interaksi dengan lingkungannya.

Sementara itu Syah (2004: 141) berpendapat bahwa penilaian terhadap tingkat keberhasilan siswa mencapai tujuan yang telah ditetapkan dalam sebuah program disebut dengan evaluasi. Tadrif (1989, dalam Syah 2004: 141) menyatakan bahwa padanan kata evaluasi adalah assessment yang berarti proses penilaian untuk menggambarkan prestasi yang dicapai seorang siswa sesuai dengan kriteria yang telah ditetapkan.

Dari beberapa pengertian prestasi tersebut diperoleh simpulan bahwa prestasi merupakan suatu proses hasil usaha yang dilakukan individu untuk memperoleh suatu perubahan tingkah laku yang baru secara menyeluruh.

Di dalam dunia pendidikan aktivitas belajar merupakan proses inti. Melalui belajar, seseorang dapat menunjukkan prestasinya.
Prestasi yang berhungan dengan bidang akademik dapat diartikan sebagai kemajuan yang dicapai seseorang berdasarkan pada kegitan belajar di sekolah. Prestasi belajar erat kaitannya dengan belajar. Untuk memahami dengan jelas tentang prestasi belajar, terlebih dahulu akan dikemukakan tentang pengertian belajar.

Dikemukakan dalam Kamus Besar Bahasa Indonesia (1995: 22) bahwa belajar berarti berusaha memperoleh kepandaian ilmu dengan cara berlatih. Winkel (1996: 53) mendefinisikan belajar adalah suatu aktivitas mental atau fisik yang berlangsung dalam interaksi aktif dengan lingkungan yang menghasilkan perubahan dalam pengetahuan, pemahaman, keterampilan, dan sikap. Perubahan itu bersifat secara relatif konstan dan berbekas.

Menurut Syah (1995 : 92) belajar adalah tahapan perubahan seluruh tingkah laku individu yang relatif menetap sebagai hasil pengalaman dan interaksi dengan lingkungan yang melibatkan proses kognitif.

Sedangkan menurut Slameto (1995: 2) belajar adalah suatu proses usaha yang dilakukan seseorang untuk memperoleh suatu perubahan tingkah laku yang baru secara keseluruhan, sebagai hasil pengalamannya sendiri dalam interaksi dengan lingkungannya.

Usman dan Setiawati (1996: 4) mengemukakan pendapatnya tentang belajar berdasarkan kutipannya dari W.H Burton dalam bukunya yang berjudul The Guidance of Learning Activities, menjelaskan pengertian belajar sebagai berikut : Learning is a change in the individual due his environment, which fells a need and makes him more capable of deadling adequately with his environment. Belajar sebagai perubahan tingkah laku pada diri individu berkat adanya interaksi an-tara individu dengan lingkungan sehingga me-reka lebih mampu berinteraksi dengan ling-kungannya.

Dari beberapa pengertian tentang belajar yang dikemukakan oleh tokoh-tokoh di atas, maka diperoleh simpulan bahwa belajar merupakan usaha untuk memperoleh kepandaian ilmu dengan cara berlatih, yang menghasilkan perubahan dalam pengetahun, pemahaman, keterampilan, dan sikap yang relatif menetap sebagai hasil pengalaman dan interaksi dengan lingkungan yang melibatkan proses kognitif.

Sudjana (1995: 55) memberikan pengertian prestasi belajar adalah kemampuan-kemampuan yang dimiliki siswa sesudah ia menerima pengalaman belajar. 
Menurut Gage dan Berliner (1979 : 82) prestasi belajar merupakan sesuatu yang dicapai atau hasil dari sesuatu yang dipelajari, dengan kata lain adalah hasil dari proses belajar yang dibantu oleh pengajaran dari kegiatan pendidikan.

Di dalam kamus psikologi dari Chaplin (1999: 5) prestasi pendidikan/akademik merupakan suatu tingkat khusus perolehan atau hasil keahlian dalam karya akademis yang dinilai oleh guru, melalui tes yang dibakukan atau melalui kombinasi kedua tersebut.

Berdasarkan pengertian tersebut, dapat disimpulkan bahwa prestasi belajar adalah kemampuan yang dimiliki siswa hasil dari proses belajar yang dibantu oleh pengajaran dari kegiatan pendidikan.

\section{Keluarga}

Menurut Suhendi dkk. (2001: 41) keluarga bisa berarti ibu, bapak, anak-anaknya atau seisi rumah. Dalam Kamus Besar Bahasa Indonesia (1995: 471) keluarga bisa juga disebut batih, yaitu seisi rumah yang menjadi tanggungan dan dapat pula berarti kaum, yaitu sanak saudara serta kaum kerabat.

Definisi lainnya, keluarga adalah suatu kelompok yang terdiri dari dua orang atau lebih yang direkat oleh ikatan darah, perkawinan, atau adopsi serta tinggal bersama (Arifin, 1993: 59).

Horton dan Hurt (dalam Suhendi, 2001: 43) memberikan beberapa pilihan dalam mendefinisikan keluarga, yaitu: a) Suatu kelompok yang mempunyai nenek moyang yang sama, b) Suatu kelompok kekerabatan yang disatukan oleh darah dan perkawinan, c) Pasangan perkawinan dengan atau tanpa anak, d) Pasangan tanpa nikah yang mempunyai anak, e) Para anggota suatu komunitas yang biasanya mereka ingin disebut sebagai keluarga.

Definisi lain dari keluarga adalah suatu kelompok yang terdiri dari dua orang atau lebih yang direkat oleh ikatan darah, perkawinan, atau adopsi serta tinggal bersama (Soekanto, 1990). Para sosiolog berpendapat bahwa asal usul pengelompokan keluarga bermula dari peristiwa perkawinan. Akan tetapi asal usul keluarga dapat pula terbentuk dari hubungan antara laki-laki dan perempuan dengan status yang berbeda, kemudian merek tinggal bersama memiliki anak. Anak yang dihasilkan da-ri hidup bersama ini disebut keturunan dari kelompok itu (Suhendi, 2001: 42).
Suhendi dkk. (2001: 42) juga menambahkan bahwa pengertian keluarga dapat dipahami dalam berbagai segi. Pertama, dari segi orang yang melangsungkan perkawinan yang sah serta dikaruniai anak. Kedua, lelaki dan perempuan yang hidup bersama serta memiliki seorang anak, namun tidak pernah menikah. Ketiga, dari segi hubungan jauh antaranggota keluarga, namun masih memiliki ikatan darah. Keempat, keluarga yang mengadopsi anak dari orang lain.

Apabila membicarakan keluarga, asosiasinya langsung tertuju pada suami isteri, anak - anak, ikatan perkawinan dan ikatan darah. Istilah yang dugunakan untuk menunjuk kelompok orang seperti itu dinamakan conjugal family, yaitu yang menunjukkan arti keluarga dalam kehidupan sehari-hari. Ada pula yang dinamakan dengan hubungan kerabat yang sedarah yang didasarkan pada pertalian darah dari sejumlah orang kerabat dan bukan didasarkan pada pertalian kehidupan suami isteri atau dinamakan consanguine family (Suhendi dkk., 2001: 53).

Manusia di satu sisi disebut sebagai makhluk individu, artinya manusia adalah pribadi yang unik dan berbeda satu dengan yang lainnya, walaupun ia kembar identik yaitu serupa tetapi tidak sama persis. Tetapi di sisi lain, manusia juga disebut sebagai makhluk sosial karena ia tidak dapat lepas dari ikatan hubungan dan interaksinya dengan individu yang lain (Wijono: 1996). Karena adanya ikatan hubungan dan interaksi inilah, membuat manusia melakukan hubungan antar pribadi yaitu hubungan antara pria dengan pria, wanita dengan wanita, dan pria dengan wanita. Hubungan antara pria dan wanita yang pada awalnya hanya bersifat sebagai teman biasa, berlanjut menjadi sahabat, yang kemudian menjadi teman dekat. Hubungan teman dekat antar pribadi, antara laki-laki dan wanita, tersebut terus berkembang maka mereka masing-masing mulai saling membuat komitmen untuk membina hubungan serius yang mereka sebut sebagai pacar atau boyfriend/girlfriend. Tahap selanjutnya, mereka juga akan memasuki jenjang yang setingkat lebih maju yaitu pertunangan. Jika proses ini berlanjut secara baik, tentu saja masing-masing mulai mempersiapkan diri untuk meneruskan hubungan lebih serius dalam ikatan pernikahan.

Sementara itu, Undang Undang Perkawinan yang dikenal dengan UU No. 1 Tahun 1974 telah menyebutkan bahwa: 
"Perkawinan adalah ikatan lahir batin antara seorang pria dan seorang wanita sebagai suami dan istri dengan tujuan membentuk keluarga (rumah tangga) yang bahagia dan kekal berdasarkan Ketuhanan Yang Maha Esa".

Dari beberapa pengertian keluarga di atas, dapat disimpulkan bahwa dalam keluarga terjalin suatu hubungan yang sangat mendalam dan kuat, bahkan hubungan tersebut bisa disebut dengan hubungan lahir bathin.

Gerungan (1964: 185) mengatakan bahwa yang dimaksud dengan keutuhan keluarga ialah pertama-tama keutuhan dalam struktur keluarga, yaitu bahwa didalam keluarga itu adanya ayah di samping adanya ibu dan anakanaknya. Apabila tidak ada ayahnya atau ibunya atau kedua-duanya, maka struktur keluarga sudah tidak utuh lagi. Juga apabila ayahnya atau ibunya jarang pulang ke rumah dan berbulan-bulan meninggalkan anaknya karena tugas atau hal-hal lain, dan hal ini terjadi secara berulang-ulang, maka struktur keluarga itu pun sebenarnya tidak utuh lagi. Selain itu, apabila orang tuanya bercerai, struktur keluarga itu dianggap sudah tidak utuh lagi.

Selain keutuhan dalam struktur keluarga, dimaksudkan pula keutuhan dalam interaksi keluarga. Jadi, bahwa di dalam keluarga berlangsung interaksi sosial yang harmonis. Apabila orang tuanya sering cekcok dan menyatakan sikap saling bermusuhan dengan disertai tindakan-tindakan yang agresif, keluarga itu tidak dapat disebut utuh (Gerungan, 1964: 185).

Gerungan (1964: 188) juga menambahkan bahwa terdapat bukti-bukti yang cukup jelas untuk menganggap, bahwa ketidakutuhan keluarga itu pada umumnya mempunyai pengaruh yang negatif terhadap perkembangan sosial anak. Pengaruh tersebut dapat diatasi atau tidak oleh anak-anak yang bersangkutan.

Dari pengertian tersebut di atas mengenai keluarga utuh dapat disimpulkan bahwa keluarga utuh adalah keluarga yang terdiri ayah, ibu, dan anak. Apabila tidak ada ayah atau ibu atau kedua-duanya, maka struktur keluaga tersebut sudah tidak utuh lagi.

Single parent adalah keluarga yang terdiri dari orangtua tunggal baik ayah atau ibu sebagai akibat perceraian dan kematian. Single parent dapat terjadi pada lahirnya seorang anak tanpa ikatan perkawinan yang sah dan pemeliharaannya menjadi tanggung jawab ibu (Hurlock, 1978 dalam Suhendi, dkk. 2001: 140). Dalam www.wikipedia disebutkan bahwa orangtua tunggal adalah a single parent is a parent who cares for children without the assistance of another person in the home. Orangtua tunggal adalah orang tua yang mengurus anaknya seorang diri.

Gerungan (1996: 201) menyebutkan bahwa keadaan rumah tangga yang tidak utuh disebut juga dengan broken home. Sedangkan menurut Shadily (1993: 367) broken home adalah suatu kondisi keluarga yang selalu cekcok atau yang tak terurus karena perceraian atau kematian dari salah satu kedua orang tuanya.

Broken home itu sendiri berasal dari bahasa Inggris, broken dan home. Broken artinya pecah, sedangkan home artinya rumah tangga, kampung halaman, rumahnya. Jadi broken home secara epistimologi adalah rumah tangga pecah. Secara terminology broken home adalah keluarga yang sudah tidak lengkap strukturnya, dapat dikarenakan antara lain : orang tua cerai, kematian salah satu orang tua atau kedua-duanya (ayah dan ibu meninggal), ketidakhadiran dalam tenggang waktu yang lama secara kontinu dari salah satu atau kedua orang tuanya (Sudharsono, 1991: 20).

Dari definisi di atas dapat dipahami bahwa broken home merupakan suatu kondisi keluarga yang strukturnya tidak utuh lagi. Ketidakutuhan tersebut disebabkan oleh kematian salah satu orang tuanya atau kedua-duanya, salah satu orang tuanya atau kedua-duanya jarang di rumah dan ini terjadi secara berulangulang, perceraian, dan interaksi anggota keluarga terjalin tidak harmonis.

Single parent yang diakibatkan oleh kematian salah satu orang tua akan menimbulkan krisis yang dihadapi anggota keluarga. Namun, menurut Polak (1979: 362) krisis yang ditimbulkan oleh kematian seorang bapak atau ibu tidaklah begitu besar pengaruhnya seperti halnya krisis yang muncul dari keluarga yang diakibatkan perceraian.

Keluarga Single parent akan mendapatkan tugas ganda. Apabila yang terjadi adalah ketiadaan ayah, peran ibu menjadi bertambah sebagai pencari nafkah dan pengasuh anak. Demikian pula sebaliknya apabila ketiadaan ibu yang terjadi, peran ayah menggantikan ibu dalam mendidik anak dan mencari nafkah.

Dampak dari kehidupan keluarga Single parent terhadap pendidikan anak sangat signifikan. Suhendi, dkk. (2001: 141) menerangkan bahwa rendahnya pendidikan akibat dari tidak 
lengkapnya orang tua dapat dibuktikan. Dampak tersebut bukan hanya karena hilangnya salah satu orang tua, melainkan ditentukan pula oleh faktor lainnya, seperti status sosial ekonomi orang tuanya dan kebiasaan dalam keluarga. Suhendi, dkk. (2001: 142) juga menambahkan status sosial ekonomi orang tua single parent terhadap pendidikan anak tidaklah mutlak, sebab hal ini juga sangat bergantung pada sikap orang tua dalam mendidik anaknya.

Dari definisi di atas dapat dipahami bahwa orangtua tunggal disebakan oleh kematian salah satu orang tua atau kedua-duanya, orang tua jarang di rumah dengan waktu yang cukup lama, perceraian, dan interaksi anggota keluarga tidak terjalin secara harmonis.

Perceraian seringkali menyebabkan pendapatan keluarga berkurang (menurun) atau mendekati taraf kemiskinan dan tentunya masalah finansial ini memiliki dampak negatif terhadap anak, seperti kesehatan, kesejahteraan, dan prestasi di sekolahnya. Biasanya ini terjadi pada keluarga dengan satu ibu yang menderita karena memiliki pendapatan yang sangat rendah, seorang ayah yang kurang mampu (gagal) memberikan dukungan pada anaknya, seperti dukungan finansial dan tidak memberikan contoh yang baik terhadap anaknya (McLanahan \& Booth, 1989 : dalam Papalia, 1998 : 327).

Dengan berbagai permasalahan yang dihadapi oleh anak yang hidup dengan satu orang tua, salah satu indikasinya adalah rendahnya prestasi mereka di sekolah. Hal ini mungkin terjadi karena orang tua lebih mementingkan masalah ekonomi keluarga daripada bagaimana anaknya berprestasi di sekolah (Papalia, 1998 : 327).

Dari pemaparan yang telah diuraikan dapat disimpulkan bahwa struktur keluarga yang berbeda dapat memberikan prakondisi (anteseden) yang berbeda bagi kehidupan seorang anak. Kondisi orang tua yang masih utuh umumnya akan memberikan lingkungan yang lebih kondusif bagi anak sehingga kemungkinan anak mengalami hambatan-hambatan psikologis akan lebih rendah daripada anak dengan orangtua tunggal, termasuk hambatan dalam belajar.

Kemungkinan prestasi anak akan lebih baik jika dukungan orang tua penuh dan motivasi belajar anak juga tinggi, adapun bagi anak yang hidup dengan orangtua tunggal karena perceraian kemungkinan mempunyai masalah psikologis yang lebih banyak, dibanding dengan anak yang hidup dengan orangtua tunggal karena meninggal dan anak yang hidup dengan orangtua utuh sehingga kemungkinan mengalami hambatan dalam proses belajar lebih tinggi.

Sedangkan hambatan dalam proses belajar bagi anak yang orang tuanya meninggal tidak seberat karena orang tua bercerai, sehingga kemungkinan prestasinya lebih tinggi daripada anak yang hidup dengan orangtua tunggal karena cerai dan lebih rendah daripada anak yang hidup dengan orangtua utuh.

Maslow (1970) mengemukakan bahwa ada beberapa kebutuhan yang terdapat dalam diri manusia. Namun kebutuhan yang ingin dipenuhi oleh manusia sifatnya hirarkis atau bertahap yaitu suatu kebutuhan akan timbul jika kebutuhan yang lebih rendah telah terpenuhi. Kebutuhan-kebutuhan yang ada dalam diri manusia itu adalah:

Kebutuhan fisiologis, yaitu kebutuhan yang berkaitan dengan kebutuhan jasmani yang diperlukan untuk mempertahankan eksistensinya sebagai makluk hidup, misalnya kebutuhan akan makan, minum, seksual dan menghirup udara yang segar.

Kebutuhan psikologis, yaitu kebutuhan yang berkaitan dengan rasa aman dan jauh dari ancaman, sosial dan cinta kasih, percaya diri dan harga diri serta aktualisasi.

Selain memiliki dampak secara psikologis, perceraian juga mempengaruhi performa anak di sekolah, yang pada akhirnya berimbas terhadap prestasinya. Sesuai dengan Block \& Block (1981; dalam Saiduddin 2003: 24) keluarga yang tidak utuh karena bercerai atau berpisah dapat memperburuk permasalahan dan mempengaruhi kemampuan anak di sekolah.

Ueyama (2007: 4) berdasarkan hasil penelitian yang dilakukannya mengatakan bahwa kematian orang tua memberikan pengaruh yang cukup signifikan terhadap peluang hidup, mobilitas serta prestasi anak di sekolah. Ia juga mengatakan bahwa kematian ibu, memiliki pengaruh yang lebih besar dibanding kematian ayah.

Pada umumnya, anak dengan keluarga orangtua tunggal dilaporkan memiliki tingkat kemandirian yang lebih dan tanggung jawab yang tinggi terhadap keluarga/rumah tangganya, lebih banyak konflik dan sedikit dukungan, kontrol ataupun hukuman dari ayahnya. Jika dibandingkan dengan keluarga utuh (Amato, 1987). 


\section{METODE PENELITIAN}

Metode yang akan digunakan dalam penelitian ini adalah metode komparasi. Menurut Arikunto (2000: 66) penelitian komparasi adalah penelitian yang dimaksudkan untuk mengetahui ada tidaknya perbedaan antara dua hal. Penelitian ini bertujuan untuk mengetahui perbandingan prestasi siswa dengan Orangtua Tunggal dan Utuh. dalam penelitian ini yang dijadikan sebagai populasinya adalah seluruh siswa kelas XII Madrasah Aliyah Negeri Cililin Kabupaten Bandung Barat. Berdasarkan studi pendahuluan, dalam penelitian ini yang dijadikan target populasi pertama adalah siswa dengan orangtua tunggal karena perceraian dan kematian yaitu sebanyak 22 siswa dan target populasi kedua adalah siswa dengan orangtua utuh sebanyak 22 siswa.

Sumber data primer yang digunakan untuk menjaring data prestasi belajar diperoleh melalui bukti tertulis rata-rata nilai raport siswa. Rata-rata nilai raport siswa yang digunakan dalam penelitian ini adalah rata-rata nilai raport yang diperoleh oleh siswa mulai dari kelas satu sampai dengan tiga. Hal tersebut dilakukan untuk mengetahui konsistensi nilai yang diperoleh.

Sumber data sekunder yang digunakan untuk menjaring data mengenai status orang tua adalah angket biodata siswa serta data hasil interview dengan siswa dan guru BP (Bimbingan dan Penyuluhan).

Untuk menetapkan signifikansi perbedaan dari dua kelompok tersebut digunakan tes $U$ Mann Whitney.

\section{HASIL DAN PEMBAHASAN}

\section{Hasil}

Berdasarkan hasil perhitungan yang diperoleh diketahui bahwa harga $p_{\text {value }}$ lebih kecil dari harga $\alpha$. Bila dibandingkan dengan kriteria uji yang dikemukakan yaitu tolak $\mathrm{H}_{\mathrm{o}}$ jika: $\mathrm{p}_{\text {value }}$ $\leq \alpha$, maka hasil yang diperoleh ini memiliki arti bahwa $\mathrm{H}_{\mathrm{o}}$ ditolak dan $\mathrm{H}_{1}$ diterima, sehingga dapat dikatakan bahwa tingkat prestasi belajar siswa dengan orangtua utuh lebih tinggi daripada tingkat prestasi belajar siswa dengan orangtua tunggal.

Selain itu dilakukan pula uji perbedaan prestasi antara siswa dengan orang tua utuh dan siswa dengan orang tua tunggal karena cerai, siswa dengan orang tua utuh dan siswa dengan orang tua tunggal karena meninggal, siswa dengan orang tua tunggal karena cerai dan siswa dengan orang tua tunggal karena meninggal dengan hasil sebagai berikut:

Perbedaan prestasi antara siswa dengan orang tua utuh dan siswa dengan orang tua tunggal karena cerai. Dengan harga $\alpha$ sebesar 0,05, $\mathrm{U}_{\text {observasi }}$ sebesar 27 dan harga $Z_{\text {hitung }}$ sebesar -2,196, maka diperoleh harga $p_{\text {value }}$ sebesar 0,0143 hasil ini diperoleh dengan membandingkan harga $Z_{\text {hitung }}$ dengan tabel $A$ dalam Siegel (1997: 299). Berdasarkan hasil perhitungan yang diperoleh diketahui bahwa harga $p_{\text {value }}$ lebih kecil dari harga $\alpha$. Bila dibandingkan dengan kriteria uji yang dikemukakan yaitu tolak $\mathrm{H}_{\mathrm{o}}$ jika: $\mathrm{p}_{\text {value }} \leq \alpha$, maka hasil yang diperoleh ini memiliki arti bahwa $\mathrm{H}_{\mathrm{o}}$ ditolak dan $\mathrm{H}_{1}$ diterima, sehingga dapat dikatakan bahwa tingkat prestasi belajar siswa dengan orangtua utuh lebih tinggi daripada tingkat prestasi belajar siswa dengan orangtua tunggal karena cerai.

Perbedaan prestasi antara siswa dengan orang tua utuh dan siswa dengan orang tua tunggal karena meninggal. Dengan harga $\alpha$ sebesar $0,05, \mathrm{U}_{\text {observasi }}$ sebesar 138 dan harga $Z_{\text {hitung }}$ sebesar $-1,129$, maka diperoleh harga $\mathrm{p}_{\text {value }}$ sebesar 0,1292 hasil ini diperoleh dengan membandingkan harga $Z_{\text {hitung }}$ dengan tabel $A$ dalam Siegel (1997: 299). Berdasarkan hasil perhitungan yang diperoleh diketahui bahwa harga $p_{\text {value }}$ lebih besar dari harga $\alpha$. Bila dibandingkan dengan kriteria uji yang dikemukakan yaitu tolak $H_{o}$ jika: $p_{\text {value }} \leq \alpha$, maka hasil yang diperoleh ini memiliki arti bahwa $\mathrm{H}_{\mathrm{o}}$ diterima dan $\mathrm{H}_{1}$ ditolak, sehingga dapat dikatakan bahwa tingkat prestasi belajar siswa dengan orangtua utuh tidak memiliki perbedaan yang signifikan dengan tingkat prestasi belajar siswa yang memiliki orangtua tunggal karena meninggal.

Perbedaan prestasi siswa dengan orang tua tunggal karena cerai dan siswa dengan orang tua tunggal karena meninggal. Dengan harga $\alpha$ sebesar $0,05, n_{l}$ sebesar 16 dan harga $n_{2}$ sebesar 6 , maka diperoleh harga $\mathrm{U}_{\text {tabel }}$ sebesar 25 hasil ini diperoleh dengan membandingkan kedua harga tersebut dengan tabel $\mathrm{K}_{\mathrm{IV}}$ (dalam Siegel, 1997 : 329). Sedangakan harga $\mathrm{U}_{\text {observasi }}$ diperoleh dengan menggunakan formula 3.1, dan diperoleh harga $U_{\text {observasi }}$ sebesar 25. Berdasarkan hasil perhitungan yang diperoleh diketahui bahwa harga $U_{\text {observasi }}$ lebih 
kecil dari harga $\mathrm{U}_{\text {tabel }}$. Bila dibandingkan dengan kriteria uji yang dikemukakan yaitu tolak $\mathrm{H}_{\mathrm{o}}$ jika: $\mathrm{U}_{\text {observasi }} \leq \mathrm{U}_{\text {tabel }}$ hasil yang diperoleh ini memiliki arti bahwa $\mathrm{H}_{\mathrm{o}}$ ditolak dan $\mathrm{H}_{1}$ diterima, sehingga dapat dikatakan bahwa tingkat prestasi belajar siswa dengan orangtua tunggal karena meninggal lebih besar daripada tingkat prestasi belajar siswa yang memiliki orangtua tunggal karena cerai.

\section{Pembahasan}

Bedasarkan hasil penelitian yang diperoleh, didapatkan gambaran bahwa tingkat prestasi belajar siswa dengan orangtua tunggal dan siswa dengan orangtua utuh kelas XII Madrasah Aliyah Negeri Cililin Kabupaten Bandung Barat menunjukkan perbedaan yang cukup signifikan, yaitu hasil perhitungan yang diperoleh untuk hipotesis mayor menunjukkan bahwa harga $p_{\text {value }}$ lebih kecil dari harga $\alpha$.

Bila dibandingkan dengan kriteria uji yang dikemukakan yaitu tolak $\mathrm{H}_{\mathrm{o}}$ jika: $\mathrm{p}_{\text {value }} \leq \alpha$, maka hasil yang diperoleh ini memiliki arti bahwa $\mathrm{H}_{\mathrm{o}}$ ditolak dan $\mathrm{H}_{1}$ diterima, sehingga dapat dikatakan bahwa tingkat prestasi belajar siswa dengan orangtua utuh lebih tinggi daripada tingkat prestasi belajar siswa dengan orangtua tunggal.

Simpulan tersebut didukung dengan konsistensi nilai rata-rata tiap semester untuk kedua kelompok. Pengujian statistik terhadap tingkat prestasi belajar antara siswa dengan orangtua tunggal dan utuh pada siswa kelas XII Madrasah Aliyah Negeri Cililin Kabupaten Bandung Barat menghasilkan empat keputusan yang berbeda, yaitu:

Pertama, tingkat prestasi belajar siswa dengan orangtua utuh lebih tinggi daripada siswa dengan orangtua tunggal. Ini terlihat dari konsistensi nilai rata-rata setiap semester siswa dengan orangtua utuh yang berada pada klasifiksi Baik dan Baik sekali. Sedangkan untuk siswa dengan orangtua tunggal, walaupun berada pada klasifikasi Baik, namun konsistensi setiap semester berbeda-beda. Hal tersebut bisa disebabkan oleh permasalahan yang dihadapi siswa, baik karena orangtua mereka bercerai ataupun karena meninngal. Menurut Block \& Block (1981; dalam Saiduddin 2003: 24) mengatakan bahwa keluarga yang tidak utuh karena bercerai atau berpisah dapat memperbu- ruk permasalahan dan mempengaruhi kemampuan anak di sekolah. Hal ini memiliki arti bahwa selain memiliki dampak secara psikologis, perceraian juga mempengaruhi performa anak di sekolah, yang pada akhirnya berimbas terhadap prestasinya.

Kedua, tingkat prestasi belajar siswa dengan orang tua utuh lebih tinggi daripada siswa dengan orang tua tunggal karena perceraian. Permasalahan yang dialami oleh siswa dengan orangtua tunggal karena perceraian menurut Tasmin (2002) merupakan masa yang paling kritis bagi anak, hal ini salah satunya disebabkan oleh berkurangnya kuantitas serta kualitas komunikasi dengan orang tua yang tidak lagi tinggal bersama. Selain itu, kemungkinan anak juga dihadapkan dengan berbagai pertanyaan atau bahkan ejekan yang muncul dari beberapa teman sebayanya. Berdasakan hal tersebut biasanya anak merasa tidak aman, merasa tidak diinginkan, sedih, kesepian, marah, kehilangan, merasa bersalah dan menyalahkan diri sendiri.

Ketiga, tingkat prestasi belajar siswa dengan orang tua utuh tidak memiliki perbedaan yang signifikan dengan prestasi belajar siswa dengan orang tua tunggal karena meninggal. Menurut Polak (1979: 362) krisis yang ditimbulkan oleh kematian seorang bapak atau ibu tidaklah begitu besar pengaruhnya seperti halnya krisis yang muncul dari keluarga yang diakibatkan perceraian.

Keempat, tingkat prestasi belajar siswa dengan orang tua tunggal karena meninggal lebih tinggi daripada siswa dengan orang tua tunggal karena perceraian. Dampak psikologis yang dialami oleh siswa dengan orangtua bercerai lebih banyak bila dibandingkan dengan siswa dengan orangtua tunggal karena meninggal.

Hasil yang diperoleh tersebut sesuai dengan salah satu asumsi yang telah dikemukakan oleh peneliti bahwa prestasi anak akan lebih baik jika diberi dukungan penuh dari orang tua dan motivasi belajar anak juga tinggi, adapun bagi anak yang hidup dengan orangtua tunggal karena perceraian kemungkinan mempunyai masalah psikologis yang lebih banyak, dibanding dengan anak yang hidup dengan orangtua tunggal karena meninggal dan anak yang hidup dengan orangtua utuh sehingga kemungkinan mengalami hambatan dalam proses belajar lebih tinggi. 


\section{SIMPULAN DAN SARAN}

\section{Simpulan}

Berdasarkan hasil analisis dan pembahasan tentang perbandingan prestasi belajar siswa dengan orangtua tunggal dan siswa dengan orangtua utuh pada siswa kelas XII Madrasah Aliyah Negeri Cililin Kabupaten Bandung Barat dapat ditarik simpulan sebagai berikut:

Terdapat perbedaan tingkat prestasi belajar antara siswa dengan orangtua utuh dan siswa dengan orang tua tunggal. Hal ini menunjukkan bahwa nilai rata-rata prestasi belajar siswa dengan orangtua utuh lebih tinggi bila dibandingkan siswa dengan orangtua tunggal.

Terdapat perbedaan tingkat prestasi belajar antara siswa dengan orangtua utuh dan siswa dengan orang tua tunggal karena perceraian. Hal ini menunjukkan bahwa nilai ratarata prestasi belajar siswa dengan orangtua utuh lebih tinggi bila dibandingkan siswa dengan orangtua tunggal karena perceraian.

Tidak terdapat perbedaan tingkat prestasi belajar yang signifikan antara siswa dengan orangtua utuh dan siswa dengan orang tua tunggal karena meninggal.

Terdapat perbedaan tingkat prestasi belajar antara siswa dengan orangtua tunggal karena meninggal dan siswa dengan orang tua tunggal karena perceraian. Hal ini menunjukkan bahwa nilai rata-rata prestasi belajar siswa dengan orangtua tunggal karena meninggal lebih tinggi bila dibandingkan siswa dengan orangtua tunggal karena perceraian

\section{Saran}

Berdasarkan hasil penelitian yang telah dilakukan, dengan memperhatikan keterbatasan-keterbatasan dalam penelitian ini, peneliti mengajukan saran-saran agar dapat dijadikan bahan pertimbangan bagi pihak-pihak yang memerlukannya sebagai berikut:

Pihak Sekolah, diharapkan mampu untuk mengoptimalkan fungsi guru BP (Bimbingan dan Penyuluhan) didalam membantu siswa yang bermasalah, khususnya siswa dengan orangtua tunggal sehingga dapat berprestasi sebagaimana siswa dengan keluarga utuh pada umumnya.

Diharapkan siswa dengan orangtua tunggal mampu memahami realitas diri (mampu bersaing), tidak larut dalam kondisi keluarga yang berbeda dengan siswa lainnya.

\section{DAFTAR PUSTAKA}

Ahmadi, Abu. 1991. Ilmu Sosial Dasar. Rineka Cipta : Jakarta.

Albin, Semmel Rochelle. 1986. EMOSI Bagaimana Mengenal Menerima dan Mengarahkannya. Kanisius: Yogyakarta.

Anonimous. 1995. Kamus Besar Bahasa Indonesia. Departemen Pendidikan dan Kebudayaan, Balai Pustaka: Jakarta.

Arifin, Tajul. 1993. Pengantar Studi Psikologi. Arie and Brother: Bandung.

Arifin, Z. 1988. Evaluasi Instruksional. Remaja Rosda Karya: Bandung.

Arikunto, Suharsimi. 2000. Manajemen Penelitian. Rineka Cipta: Jakarta.

Ashshiddiqi, Hasbi. dkk. 1971. Al-Qur'an dan Terjemahannya: Jakarta.

Azwar, Saefudin. 2004. Penyusunan Skala Psikologi. Pustaka Pelajar Offset: Yogyakarta.

Dagun, M. Save. 1989. Psikologi Keluarga. Rineka Cipta : Jakarta.

Depdikbud. 1997. Kamus Besar Bahasa Indonesia. Balai Pustaka: Jakarta.

Effendi, Mudor. 1993. Peran Ibu dalam Rumah Tangga. Fakultas Syari'ah IAIN Sunan Gunung Djati: Bandung.

Gerungan, W.A. 2002. Psikologi Sosial. Reflika Aditama: Bandung.

Hadi, Sutrisno. 2001. Metodologi Research. Andi: Yogyakarta.

Langgulung, Hasan. 1986. Beberapa Pemikiran Tentang Pendidikan Islam. Al-Ma'arif: Bandung.

Maslow, A.H. (1970). Motivation and Personality. Second Ed. Harper dan Row Publisher: New York.

Najati, 'Utsman Muhammad. (2000). Psikologi Dalam Tinjauan Hadits Nabi SAW. Daarusy-Syuruuk : Kairo.

Nasir, H. Sahilun. 1999. Peran Pendidikan Agama Terhadap Pemecahan Problema Remaja. Kalam Mulia: Jakarta.

Nazir, Moh. 1985. Metode Penelitian. Ghalia Indonesia : Jakarta.

Polak, J. B. Af Mayor. 1979. Sosiologi Suatu Buku Pengantar Ringkas. PT. Ikhtiar Baru : Jakarta.

Rahayu, Rena. 2002. Respon Siswa terhadap Usaha Guru untuk Membangkitkan Perhatian dalam Proses Belajar Mengajar Mereka pada Bidang Studi Matematika; Penilaian di Kelas I SMPN Maja Kab. 
Majalengka. Skripsi. Tidak diterbitkan: UIN Bandung.

Ramayulis. 1996. Pendidikan Islam dalam Rumah Tangga. Kalam Mulia: Jakarta.

Riberu, J. 1985. Kemelut Anak, Remaja, dan Problema Kekeluargaannya. Mega Media: Jakarta.

Riduwan. 2005. Skala Pengukuran Variabelvariebel Penelitian. Alfa Beta: Bandung.

Shadily, Hasan. 1993. Sosiologi untuk Masyarakat Indonesia. Rineka Cipta: Jakarta.

Shihab, Quraisy. 2002. Tafsir Al-Misbah. Lentera Hati : Jakarta.

Siegel, Sydney. 1994. Nonparametric Statistics for the Behavioral Science (edisi terjemah). PT Gramedia : Jakarta.

Slameto. 1993. Belajar dan Faktor-faktor yang Mempengaruhinya. Rineka Cipta: Jakarta.

Suhendi, Hendi. Dkk. 2001. Pengantar Studi Sosiologi Keluarga. Pustaka Setia. Bandung.

Sudjana. 1996. Metoda Statistika edisi keenam. Tarsito: Bandung.

Soekanto, Soerjono. 1990. Sosiologi Keluarga tentang Ikhwal Keluarga, Remaja dan Anak. Rineka Cipta: Jakarta.

Suryabrata, S. 1993. Psikologi Pendidikan. Raja Grapindo: Jakarta.

Syah, M. 1996. Psikologi Pendidikan suatu
Pendekatan Baru. Rosda Karya:

Bandung.

Undang-undang Sisdiknas No. 20. Tahun 2003. Fokusmedia. Bandung.

Usman, U \& Setiawati, L. 1996. Menjadi Guru Profesional. Remaja Rosda Karya: Bandung.

Walczak, Yvette \& Burns Sheila. 1984. Divorce: The Child's Point Of View. Harper \& Row, Publishers: London.

Wantjik, S.K. 1976. Hukum Perkwinan Indonesia. Ghalia Indonesia: Jakarta.

Winkel, WS. 1995. Psikologi Pengajaran. Rineka Cipta : Jakarta.

Yusuf L. N, Syamsu. 2001. Psikologi Perkembangan Anak dan Remaja. Remaja Rosda Karya. Bandung.

Zulkarnaen, Diki S. 2007. Problematika Anak. Tidak diterbitkan. www. e-psikologi.

Tasmin, S. Rini, Martina. 2002. Perceraian dan Kesepian Mental Anak. Tidak diterbitkan. www. e-psikologi.

Wijono, Sutarto. 2003. Nampak Utuh Tetapi Rapuh (Suatu Tinjauan Psikologis Terhadap Keluarga). Tidak diterbitkan. webmaster(at)sabda.org

www.acehforum.or.id/-Keluarga Islam dan Konsep Amanah oleh: Dra. Hj. Lenny Oemar

www.republika.co.id 